International Journal of Science and Education, 4(3), 207-225

Uluslararası Bilim ve Eğitim Dergisi, 4(3), 207-225

DOI: $10.47477 /$ ubed. 840868

Makale Türü: Araştırma Makalesi

Başvuru Tarihi: 14.12.2020

Yayına Kabul Tarihi: 21.12.2021

\title{
Akıl ve Zekâ Oyunlarının Öğrencilere Katkıları: Eğitmenlerin Görüşleri
}

\author{
Bekir KUL ${ }^{1 *}$, Sezgin KEL ${ }^{2}$
}

Öz

Bu çalışmanın amacı Millî Eğitim Bakanlığına bağlı resmî kurumlarda görev yapan akıl ve zekâ oyunları eğitmenlerinin akıl ve zekâ oyunlarının öğrencilere katkıları hakkındaki görüşlerini belirlemektir. Tarama modelinde yürütülen çalışmaya amaçlı örnekleme yöntemi ile belirlenen 317 akıl zekâ oyunları eğitmeni katılmıştır. Millı̂ Eğitim Bakanlığı tarafından mahallî olarak düzenlenen zekâ oyunları 1 ve 2 kursuna katılan öğretmenler ve idareciler; ortaokullarda seçmeli zekâ oyunları dersine giren öğretmenler; okul öncesi, ilkokul, ortaokul ve lise kademelerinde görev yapan ve halk eğitim merkezleri aracılığı zekâ oyunlarıyla ilgili kurs açan öğretmenler oluşturmaktadır. Analiz sonuçlarına göre akıl ve zekâ oyunları eğitmenlerinin zekâ oyunlarının öğrencilere katkısı ile ilgili görüşleri cinsiyet, yaş ve görevleri bakımından anlamlı bir farklılık göstermemektedir. Ancak kıdem değişkeninde gruplar arası farklılıkların olduğu tespit edilmiştir. Ayrıca akıl ve zekâ oyunları eğitmenlerine göre; akıl ve zekâ oyunları matematik dersine karşı tutum, üst düzey düşünme becerileri, öğrenci başarısı ile matematiksel beceriler üzerinde pozitif yönde etkilidir. Son olarak katılımcılar; akıl ve zekâ eğitimi alan öğrencilerin matematik dersine karşı tutumları, üst düzey düşünme becerileri, başarıları ile matematiksel becerilerinin birbirleriyle pozitif yönde ilişkili olduğunu belirtmişlerdir.

Anahtar Kelimeler: Akıl-zekâ oyunları, akıl yürütme, problem çözme becerisi, düşünme becerisi

\section{The Contribution of Mind and Intelligence Games to Students: Views of Instructors}

\begin{abstract}
The aim of this study is to determine the opinions of mind and intelligence games trainers working in official institutions affiliated to the Ministry of National Education about the contribution of mind and intelligence games to students. 317 mind games trainers, who were determined by the purposeful sampling method, participated in the study carried out in the survey model. Teachers and administrators who participated in the intelligence games 1 and 2 courses organized locally by the Ministry of National Education; teachers who teach elective intelligence games in secondary schools; pre-school, primary, secondary and high school and teachers who open courses on intelligence games through public education centers. According to the results of the analysis, the opinions of the mind and intelligence games instructors about the contribution of the mind games to the students do not show a significant difference in terms of gender, age and duties. However, it was determined that there were differences between the groups in the seniority variable. In addition, according to mind and intelligence games trainers; Mind and intelligence games have a positive effect on attitudes towards mathematics, high-level thinking skills, student success and mathematical skills. Finally, the participants stated that the attitudes, higher-order thinking skills, achievements and mathematical skills of the students who received mind and intelligence education were positively related to each other.
\end{abstract}

Key Words: Mind-intelligence games, reasoning, problem solving skill, thinking skill

1*Corresponding Author: Dr. MEB Uzmanı, Milli Eğitim Bakanlığı, Türkiye, bekirkul@hotmail.com, ORCID: 0000-0001-6687717X

${ }^{2}$ Müdür Yardımcısı, Isparta Şehit Ali Yılmaz Borsa İstanbul İlkokulu, Türkiye, sezginkelsezgin@gmail.com, ORCID:0000-00020721-7208 


\section{Giriş}

Toplumsal gelişme ve kalkınmanın ön koşulu nitelikli insan gücü, nitelikli insan gücünün temel kaynağı ise nitelikli eğitimdir (Güneş ve Demirtaş, 2002). Eğitim sistemimiz bilim ve teknolojideki gelişmeler ışığında sürekli değişime uğramaktadır. Son dönemde değişime uyum sağlamak ve dünya ile sürdürülebilir rekabet gücü oluşturabilmek için düşünce, hayal gücü ve yaratıcılık gibi becerileri kullanarak bilişsel yeterliliklerin ve kapasitenin oluşturulması gerekliliği ön plana çıkmıştır. Bu gelişmelerle birlikte öğrencilerin bilgiye ulaşma sürecinde aktif bir şekilde yer alması, öğrenmenin öznesi konumuna gelmesi fikri oldukça yaygındır. Yapılandırmacılık eğitim anlayışının benimsenmesi ile birlikte ezberci ve kalıplara dayalı klasik öğrenme sistemi bir kenara bırakılarak; öğrenmede öğrenciyi merkeze alarak, öğrencinin düzeyine uygun öğrenme yöntemteknikleriyle araştırmaya ve isteyerek öğrenmeye olanak sağlayan, öğrenme sürecinde öğrenenin etkin rol aldığı, öğrencinin öğrenmeye ulaşmada birincil aktör olduğu, öğretmenin öğretim sürecinde öğrencinin öğrenmesini kolaylaştırması açısından rehber, kılavuz ve yardımcı olduğu bir noktaya gelinmiştir.

21. yy dünyası; öğrencilerden güçlü bir dikkat ve algı yeteneği, eleştirel, analitik ve yaratıcı düşünme, problem çözme, sosyal zekâ ve iletişim becerileri talep etmektedir. Öğrencilerin günlük hayatta karşılaştığı problemlere yönelik farklı ve özgün çözüm yolları üretmeleri, hızlı ve doğru karar vermeleri, sebep sonuç bağlantıları oluşturmaları, disiplinler arası ilişkiler kurmaları, eleştirel düşünmeleri ve yaşam becerilerinin geliştirilmesi amaçlanmaktadır. Günümüzde okullarda eğitim öğretim yoluyla öğrenenlerin problem çözme, akıl yürütme ve çok boyutlu düşünme gibi üst düzey yaşam becerilerinin geliştirilmesi sürecinde oldukça çeşitli ve alternatif öğretim yöntem ve yaklaşımlarına başvurulduğu görülmektedir. Hiç şüphesiz ki bu alternatif yaklaşımlardan biri de genel çerçevede oyunlar (Gündüz ve diğerleri., 2017), daha özelde ise zekâ oyunlarıdır (Adalar ve Yüksel, 2017). Bu gerekçeler bağlamında ülkemiz eğitim sisteminde erken yaşlarda itibaren akıl ve zekâ oyunları öğretiminin önemi giderek artmaya başlamıştır.

Hızla gelişen dünyamızda öğrencilerin gereksinim duydukları analitik, eleştirel ve yaratıcı düşünme becerisi, işbirliği, takım çalışması, girişimcilik, sözlü ve yazılı iletişim becerileri, merak, hayal gücü, bilgiye erişme, bilgiyi analiz etmek gibi üst düzey düşünme becerilerinin geliştirilmesinde ve akademik başarılarının artırılmasında akıl ve zekâ oyunları, eğitim sürecinin en önemli argümanlarından biri haline gelmiştir (Ott ve Pozzi, 2012; Bottino ve diğerleri., 2013). Akıl ve zekâ oyunları ile bu becerileri geliştirmek daha kolay olacaktır. Bu oyunlar, öğrencilerin günlük yaşamda karşılaştıkları problemleri çözebilmeleri için bazı düşünme becerileri ve stratejileri ortaya çıkarmalarına yardımcı olmaktadır (Muller ve Pearlmutter, 1985). Ayrıca öğrencilerde bilişsel becerilerin gelişmesine önemli katkılar sunmasının yanında, zamanı etkili, verimli kullanmalarını sağlama ve eğlenceli vakit geçirme alışkanlığı da kazandırılabilir.

Milli Eğitim Bakanlığı öğrencilerin zihinsel potansiyellerinin farkına varması ve bilişsel becerilerinin geliştirilmesi amacıyla 2013-2014 Eğitim Öğretim yılından itibaren ortaokul kademesinde 5. 6. 7. 8. Sınıflarda Seçmeli Zekâ Oyunları Dersini programa eklemiştir. Okul Öncesi, İlkokul, Ortaokul ve Lise Kademelerinde Halk Eğitim Merkezleri aracılığı ile Zekâ Oyunları Eğitim almış Öğretmenler tarafından "Geleneksel Oyunlar ve Zekâ Oyunları" alanında; "Zekâ Oyunları Başlangıç Düzeyi" , "Zekâ Oyunları Orta Düzeyi" "Zekâ Oyunları İleri Düzeyi", "Zekâ Oyunları Okul Öncesi" kursu açılmaktadır. Yükseköğretim kurumlarında ise bu dersi ve bu derse ilişkin öğretim programını tanıtmak ve bu dersin öğretimi konusunda öğretmen adaylarını daha yetkin hale getirmek amacıyla lisans ve yüksek lisans düzeyinde seçmeli ders olarak öğretim programlarında yer almaktadır.

Zekâ oyunları dersi; Sözel oyunlar, Hafıza Oyunları, Geometrik ve Mekanik Oyunlar, Akıl Yürütme ve İşlem Oyunları, Strateji Oyunları ve Zekâ Soruları olmak üzere 6 kategoriden ve öğrencilere basitten karmaşığa, kolaydan zora, bilinenden bilinmeyene giden, aşamalılık gösteren 
öğrenme imkânları sunan, farklı yetkinlik düzeylerine uygun olarak bu farklılığı barındıran öğrencilerin aynı sınıfta yer alabileceği basamaklı öğretim yaklaşımı benimsemektedir (MEB, 2013).

İlköğretim Seçmeli Zekâ Oyunları Dersi Öğretim Programı 3 basamaktan oluşmaktadır;

1. Basamak (Başlangıç Düzeyi): Oyunların kurallarını öğrenmeyi, temel bilgi ve becerileri kazanmayı, başlangıç düzeyi oyunları oynamayı ve bulmacaları çözmeyi içerir.

2. Basamak (Orta Düzey): Mantıksal çıkarımlarda bulunmayı, bulmacalarda doğru yerden başlamayı, strateji oyunlarında temel stratejileri uygulamayı, orta düzey oyunları oynamayı ve bulmacaları çözmeyi içerir.

3. Basamak (İleri Düzey): Yaratıcı düşünme, analiz etme, özgün stratejiler ortaya koyma, değerlendirme, genelleme yapma gibi üst düzey bilgi ve becerileri içerir. İleri düzey oyunlar oynama, bulmacaları çözme ve başkalarının deneyimlerinden yararlanma bu basamak içinde yer alır (MEB, 2013).

Özellikle son dönemde yapılandırmacılık, çoklu zekâ kuramı ve oyun temelli öğrenme gibi yaklaşımlara büyük önem verilmesine rağmen bunlarla yakından ilişkili olan akıl ve zekâ oyunları konusunda çok az çalışma yapılmıştır. Bu çalışmanın amacı öncelikle akıl ve zekâ oyunları konusunda literatüre katkı sağlamak, bunun yanında akıl ve zekâ oyunları etkinliklerinin; öğrenci davranışlarına, öğrencilerin sayısal becerilerinin geliştirilmesine ve eğitim öğretim sürecine katkısını ortaya çıarmaktır.

21. Yüzyıl; dünya ile rekabet eden liderler yetiştiren, değişen dünyaya uyum sağlayan, öğrendiği bilgileri uygulamaya dönüştüren, analiz, sentez ve değerlendirme yapan, yenilikçi ve üretken özelliklere sahip nitelikli insan kaynağına ihtiyaç duymaktadır. Bu özelliklere sahip olan bireylerde; yaratıcılık ve yenilenme, liderlik ve sorumluluk, iletişim ve işbirliği, üretkenlik ve hesap verebilirlik, bilgi, medya ve teknoloji becerileri, eleştirel, analitik, düşünme ve problem çözme becerilerinin olması gerekliliği ön plana çıkmaktadır. Yapılan çalışmalar sonucunda bu kavramların geliştirilebilir olduğuna dair ulaşılan sonuçlar günümüz bireylerine verilmesi gereken eğitimin özelliklerini de belirlemektedir (Ellis ve Hunt, 1993; Lester, 1994; Verschaffel, Corte ve diğerleri, 1999; NCTM, 2000).

Öğrencilerden davranışlara dönüşmesi beklenen analitik düşünme, eleştirel düşünme, stratejik düşünme becerisi, problem çözme ve yaratıcı düşünme gibi üst düzey düşünme becerilerinin geliştirilmesinde ve okul başarılarının artırılmasında etkili olan oyun türlerinden biri de akıl ve zekâ oyunlarıdır. Akıl ve zekâ oyunlarının öğrencilerin zekâ gelişimine olan etkisi üzerinde yapılan farklı araştırmaların ortaya koyduğu üzere bu oyunlar sadece öğrencilerin zekâ gelişimini değil, aynı zamanda öğrencinin düşünsel gelişimini de desteklemektedir. Mackey, Hill, Stone, Bunge (2011) gerçekleştirdikleri araştırmada; 2., 3., 4. sınıf öğrencileri, dersten sonra haftanın iki günü 1 saat 15 dakika olmak üzere farklı zihinsel işleyişler gerektiren kullanıma hazır kutu oyunları ve kart oyunları oynamışlardır. 8 hafta boyunca toplamda 20 saat süren eğitim programı, bilişsel testlerde 13 puanlık bir artış sağladığı dolayısıyla akıl yürütme, işlem hızı gibi bilişsel süreçlerin oyun eğitimiyle değiştirilebilir ve geliştirilebilir olduğunu kanıtlamışlardır. Zekâ oyunları her yaş grubundan bireyin zihinsel becerisini geliştiren, pek çok bilginin eğlenceli bir ortamda öğrenilmesini sağlar. Akıl ve zekâ oyunları; öğrencilerin eğlenirken zekâsını geliştirmesi, zihnini açması, yeni bir şeyler öğrenmesi, beynin farklı bölgelerinin çalışmasını sağlamak için hazırlanmış oyunlardır. Bu oyunlar öğrencilerin sadece yeteneklerin geliştirmekle kalmayıp, kötü alışkanlıklar edinmelerine de engel olur.

Öğrenciler, akıl ve zekâ oyunlarında ilerleme sağladıkça kendilerine olan özgüvenlerinin arttı̆̆ını gösteren çalışmalar bulunmaktadır. Zekâ oyunlarının; öğrencinin motivasyonu arttırma 
(Rosas ve diğerleri, 2003), dikkat ve konsantrasyonu arttırma (Garris, ve diğerleri, 2002), öğrenmeye yönelik olumlu tutum geliştirme (Lou, ve diğerleri, 2001) gibi davranışa yönelik katkılarından da söz edilebilir. Bu katkı sayesinde öğrencilerin okulda öğretmenini dinlerken ve ders çalışırken konsantre olmasına yardımcı olarak, akademik başarısının artmasına katkı sağlayacaktır.

Akıl ve zekâ oyunlarının bir diğer önemi ise öğrenciye her zaman daha etkin bir çalışma yöntemi sunmaktır. Her farklı oyunda öğrenci kendisini tanımakta ve akranlarıyla birlikte kendisini değerlendirmeyi öğrenmektedir. Christine Gorss Loh, Parenting Without Borders 'Sınırlar Olmadan Ebeveynlik' adlı çalışmasında çocukları her zaman daha iyisini yapabilecekleri etkinliklere teşvik etmenin önemini anlatmıştır. Ayrıca, bu çalışmada akıl ve zekâ oyunlarının yaygın olarak oynandığı Japonya'da; ailelerin bu oyunlara önem verdiği ve çocuğun yapamadığı ya da kendisini akranlarıyla değerlendirdiği durumlarda onları her zaman daha iyisini yapabilecekleri konusunda yüreklendirdikleri vurgulanmıştır.

Literatürde akıl ve zekâ oyunlarının farklı tanım ve açılamaları bulunmaktadır. Bunlardan bazılarına aşağıda yer verilmiştir.

Akıl ve Zekâ Oyunları; çağın ihtiyaç duyduğu kalifiye insan gücü oluşturmak için farklı yapıda araç ve gereç kullanarak, bireylerde özgün bakış açısı oluşturan, hızlı ve doğru karar verebilme yetisini geliştiren, yeni ve farklı ürünler ortaya koyma noktasında yaratıcı düşünme becerisini geliştiren, bireyin sosyalleşmesinde etkili olan, vaktini eğlenceli ve öğretici geçirerek teknoloji bağımlılığı azaltılması sürecinde rol oynayan, zihinsel kapasite becerisini artıran her türlü problemin oyunlaştırılmış halidir (MEB, 2013). Akıl ve zekâ oyunları öğrencilerde planlı hareket etme becerisi, sistematik düşünme becerisi, çok yönlü düşünme yeteneği, ezbercilikten uzaklaştırarak araştırma becerisini geliştirmeyi, eğlenerek öğrenmeyi, problemlere karşı çözüm yolu üretme gibi bazı düşünme becerileri ve stratejileri ortaya çıkarmalarını gerektirmektedir (Demirel ve Yılmaz, 2016).

Zekâ oyunları dersinde öğrencilerin zekâ potansiyellerini tanıması ve geliştirmesi, problemler karşısında farklı ve özgün stratejiler geliştirmesi, hızlı ve doğru karar vermesi, sistematik bir düşünce yapısı geliştirmesi, zekâ oyunları kapsamında bireysel, takım halinde ve rekabet ortamında çalışma becerileri geliştirmesi ve problem çözmeye yönelik olumlu bir tutum geliştirmesi amaçlanmaktadır (MEB, 2013). Zekâ oyunlarının öğrencilere kazandırdığı beceriler Şekil 1 de gösterilmektedir.

Akıl ve Zekâ Oyunlarını; Milli Eğitim Bakanlığı Talim Terbiye Kurulu'nun Ortaokul ve İmam hatip Ortaokulları için hazırlamış olduğu Seçmeli Zekâ Oyunları Öğretim Programında 6 kategoride sınıflandırılmıştır.

1. Verilen ipuçlarından yola çıkarak ve mantıksal çıkarımlarla adım adım ilerlenebilen, dört işlem becerisini kullanılan, genellikle tek kişi tarafından oynanan oyunlardır. Kâğıt kalem oyunu olarak da adlandırılan Akıl yürütme ve işlem oyunları öğrencilerin sayısal ve işlem becerilerini geliştiren oyun türüdür. Örneğin; sudoku, apartmanlar, kendoku, kakuro, işlem karesi, sayı bulma, kapsül gibi oyunlar akıl yürütme ve işlem oyunları kategorisinde yer almaktadır.

2. Kelime haznesi ve genel kültür bilgi kapasitesi yolu ile mantıksal çıkarımların yapılarak bireysel veya takım oyunu halinde gerçekleştirilen oyunlardır. Kelime avı, hikâye küpleri, anagramlar, şifre bulma, kelime bulma, sözcük gruplama sözel oyunlar kategorisinde yer almaktadır.

3.Geometrik ve mekanik oyunlar; öğrenci görsel, uzamsal ve geometrik düşünme becerilerini kullanarak oyun araç ve gereçleri ile gerçekleştirdiği oyunlardır. Soma küpleri, jenga, tangram, mikado ve rubik küpü geometrik ve mekanik oyunlar kategorisinde yer almaktadır. 
4. Hafıza oyunları, zihinsel bellek yardımı ile bireysel, karşılıklı ya da takım olarak oynanan oyunlardır. Sayı hatırlama, resim hatırlama, eş ve yön bulma oyunları hafıza oyunları kategorisinde yer almaktadir.

5. Strateji Oyunları; iki ya da daha fazla kişi tarafından oynanabilen anlama, analiz etme, yordama, çözüm yolu geliştirme, çözümü deneme, sınama, doğrulama ya da yanlışlama, revize etme gibi üst düzey bilişsel becerileri kullanılarak öğrencilerde stratejik düşünme becerisini geliştiren oyunlardır. Strateji oyunları, bir problem durumundan kazanan olarak çıkmayı, bir görevi (rakipten önce) başarmayı ve bunları sistematik olarak sağlayabilmek için de bir takım bilişsel şemaların kurulmasını zorunlu kılmaktadır. Mangala, reversi, pentago, go, kulami, hedef 5, koridor, tic tac to ve benzeri oyunlar "strateji oyunları" kategorisinde yer almaktadır.

6. Zekâ Soruları; çözümü başlangıçta net olmayan, verilen ipuçları yardımı ile kesin sonuçlara ulaşılabilen, bir veya birden çok kilit fikre dayanan oyunlardır. Örüntü, fener ve köprü, kibrit çöpleri ile eşitlik sağlama, kurt, kuzu ve otun tek sandalla nehrin karşısına geçirilmesi oyunlar zekâ soruları kategorisinde yer alır.

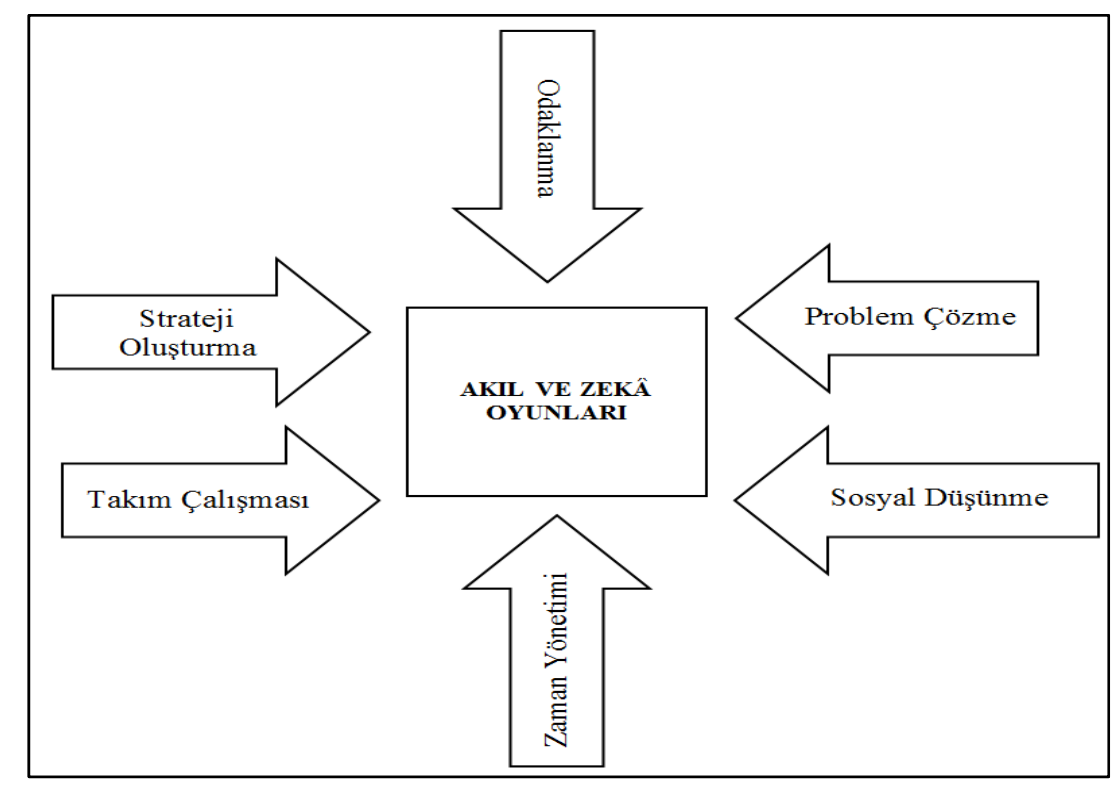

Şekil 1. Zekâ Oyunları Kazanımları

Sekil 1'de görüldüğü gibi zekâ oyunları öğrencilerin 21. yy becerileri arasında yer alan stratejik düşünme, takım üyesi olma ve takım çalışmalarına uyum sağlama, odaklanma, problem çözme, soyut düşünme ve zaman yönetimi gibi temel becerileri kazanmalarına katkı sağlamaktadır.

Milli Eğitim Bakanlığı öğrencilerin farklı oyunlar ve etkinliklerle bilişsel yeterliklerinin, becerilerinin geliştirilmesinde zekâ oyunlarının etkili ve verimli eğitsel bir araç olacağı öngörüsüyle hareket ederek "Seçmeli Zekâ Oyunları Öğretim" programını hazırlamıştır. Esnek tasarıma uygun, katılım ve gelişme esaslı, her sınıfın deneyimine ve koşullarına göre farklı kategorilerde farklı zorluk derecelerinde oyunlar seçerek planlanabilen, her kategori için üç zorluk derecesi tanımlı bir yapıya sahiptir.

Ülkemizde Zekâ Oyunları ile ilgili ilk çalışmalar 2012 yılında başlamıştır. 2013 yılında Milli Eğitim Bakanlığı Talim Terbiye Kurulu tarafından Zekâ Oyunları Öğretim Programının tamamlanması ile Ortaokullarda ve İmam Hatip Ortaokullarında Seçmeli Ders olarak okutulmaya 
başlanmıştır. 2016 yılında Seçmeli Zekâ Oyunları Öğretmen Kılavuz Kitabının yazılımı ile bu alana önemli bir fayda sağlamıştır. Milli Eğitim Bakanlığı Merkezi Zekâ Oyunları Eğitici Eğitimlerine 2015 yılında Rize Hizmet içi Eğitim Merkezinde, zekâ oyunları kurslarını illerde verebilecek eğiticileri yetiştirmek amacıyla düzenlemiştir. Bu kursa katılım şartı daha önce zekâ oyunları kursundan herhangi birine katılmış olan öğretmenlerin katılımı ile gerçekleştirilmiştir.

İlerleyen süreçte Öğretmen Yetiştirme ve Geliştirme Genel Müdürlüğü tarafından bir plan dâhilinde hazırlanan Yıllık Hizmet içi Eğitim Planı doğrultusunda eğitimleri sürdürmeye devam etmiştir. Merkezi Zekâ Oyunları Eğitici Eğitimini başarı ile tamamlayan öğretmenler çalıştıkları illerde Zekâ Oyunları Eğitici Eğitmeni unvanına sahip olarak, mahalli hizmet içi kurslarına katılım sağlayan öğretmenlere "Zekâ Oyunları" dersi ve kursu gerçekleştirecek öğretmenlere bilgi ve beceri kazandırmak amacı ile Zekâ Oyunları-1 (30 saat) ve Zekâ Oyunları-2 (30 saat) kurs eğitimi düzenlemişlerdir.

Kursu başarı ile tamamlayan öğretmenler zekâ oyunları eğitmeni olarak Milli Eğitim Temel Kanunu'nda belirtilen genel amaçlar çerçevesinde, zekâ oyunları dersinde öğrencilerin zekâ potansiyellerini tanıması ve geliştirmesi, akı yürütme ve işlem becerisi kazandırması hedeflenmektedir. Ayrıca öğrencilerin sistematik düşünce yapısı oluşturması, problemler karşısında farklı ve özgün stratejiler geliştirmesi, problemleri algılama ve değerlendirme kapasitelerinin geliştirilmesi, problemle karşılaştıklarında hızlı ve doğru karar verebilmeleri, üst düzey bilişsel becerileri kazanması amacı ile anasınıfı, ilkokul, ortaokul ve lise kademesinde öğrencilere halk eğitim merkezleri aracılığı ile planlanan kursları düzenlemektedirler.

Milli Eğitim Bakanlığı Hayat Boyu Öğrenme Genel Müdürlüğü halk eğitim merkezleri aracılığı ile zekâ oyunları alanında çeşitli kurslar planlamıştır. 2017 yılında mangala 1 ve mangala 2 kurs modülünü, 2018 yılında öğretmenler için 44 saatlik zekâ oyunları öğreticiliğ̈i kursunu, 40 saatlik go oyunu öğreticiliği kursunu, her yaşa yönelik 80 saatlik zekâ oyunları kurs modülünü, 2019 yılında son güncelleme ile 100 saatlik zekâ oyunları okul öncesi kurs modülünü, 150 saatlik zekâ oyunları başlangıç düzeyi kurs modülünü, 150 saatlik zekâ oyunları orta düzeyi kurs modülünü, 150 saatlik zekâ oyunları ileri düzeyi kurs modülünü planlamıştır.

Eğitim sistemimizde zekâ oyunları öğretimine olan ilginin yaygınlaşarak artması sonucunda; okul öncesi, ilkokul ve lise kademelerinde görev yapan öğretmenler ders dişında, zekâ oyunları başlangıç seviyesi kursunu, ortaokullarda ise seçmeli zekâ oyunları dersinde ve yine ders dışı zaman diliminde zekâ oyunları başlangıç seviyesi kurs eğitimlerini düzenlemektedirler. Ayrıca bu alanla ilgilenen sivil toplum kuruluşlarının sayısında gözle görülebilir oranda artış olması ülkemizde zekâ oyunları kültürünün yaygınlaşmasında önemli bir rol üstlenmektedir.

Dünya Zekâ Oyunları Federasyonu'nun (World Puzzle Federation) Türkiye temsilcisi olan Türk Beyin Takımı, Türk Zekâ Vakfı, Tüm Akıl ve Zekâ Oyunları Federasyonu ve benzeri kuruluşlar bu alanda ilk olarak akla gelen sivil toplum kuruluşlarıdır. Bu kuruluşlar Milli Eğitim Bakanlığı'nın ilgili birimleriyle protokoller imzalayarak işbirliği içerisinde çeşitli faaliyetler yürütmektedirler. $\mathrm{Bu}$ kapsamda gerçekleştirilen kongre, konferans ve seminerler, öğretmen eğitimleri, yeni eğitim programlarının geliştirilmesi, ilgili konulardaki kitap-dergi yayınları, akıl ve zekâ oyunları tasarımları, ulusal akıl ve zekâ oyunları turnuva ve yarışmaları, öğrencilerin zekâ potansiyellerinin zihinsel becerilere dönüşmesine yardımcı olmaktadır.

Millî Eğitim Bakanlığı ve sivil toplum kuruluşları tarafından gerçekleştirilen çalışmaların yanında ülkemizde ilgili konularda farklı bakış açılarını ve değişkenleri içeren akademik çalışmalar da yapılmıştır. Devecioğlu ve Karadağ tarafından (2014) “Amaç, Beklenti ve Öneriler Bağlamında Zekâ Oyunları Dersinin Değerlendirilmesi" adlı bir çalışma gerçekleştirilmiştir. Betimsel olarak analiz 
edilen anket verilerine dayanarak Zekâ Oyunları Dersinin (ZOD) amaçları tanımlanmış ve bu alanda kazanımların artırılmasına ve problemlerin giderilmesine yönelik öneriler sunulmuştur. Ülkemizin beyin gücünün artmasında çok önemli katkıları olacağına inanılan ZOD ile tanımlanacak hedef ve davranışların öğrencilere kazandırılmasının, öğrencilerin bilişsel, duyuşsal ve devinişsel yeterliklerinin gelişiminde ve gelişmiş insan gücünün oluşturulmasında çok önemli olduğuna, bu nedenle de ZOD dersine gereken önemin verilmesi gerektiğine sonuçlarından söz etmişlerdir. 2019 yılında yapılan ve zekâ oyunlarının ilkokul 2. sınıf öğrencilerine yansımalarının incelendiği araştırma sonuçlara göre; zekâ oyunlarının öğrencilerin özgüven, iletişim, empati, düşünme becerileri ve işbirlikçi çalışma gibi becerilerini geliştirmeye katkı sağladığı, bunu yanında derslere aktif katılımı ve motivasyonu artırdığı görülmüştür. Ayrıca öğrencilerin oyunda yenildikleri zaman başarısızlık hissi yaşadıkları ve bununla baş etmeye çalıştıkları sonuçlarına ulaşılmıştır (Kula, 2019).

$\mathrm{Bu}$ çalışmada ise akıl zekâ oyunlarının öğrencilere olan katkıları konusunda akıl-zekâ oyunları eğitmenlerinin görüşleri ele alınmaktadır. Yerli ve yabancı literatürde konuyla ilgili yapılan çalışmalar da göz önünde bulundurularak aşağıdaki hipotezler oluşturulmuştur:

H1. Akıl ve zekâ oyunları eğitmenlerinin zekâ oyunlarının öğrencilere katkısı ile ilgili görüşleri cinsiyet, yaş, görev, kıdem ve çalıştıkları okul kademesi değişkenlerine göre farklılık göstermektedir.

H2. Akıl ve zekâ oyunları eğitmenlerine göre; akıl ve zekâ oyunları matematik dersine karşı tutum, üst düzey düşünme becerileri, öğrenci başarısı ile matematiksel beceriler üzerinde pozitif yönde etkilidir.

H3. Akıl ve zekâ oyunları eğitmenlerine göre; akıl ve zekâ eğitimi alan öğrencilerin matematik dersine karşı tutumları, üst düzey düşünme becerileri, başarıları ile matematiksel becerileri gibi özellikleri birbirleriyle pozitif yönde ilişkilidir.

\section{Yöntem}

Bu çalışmada tarama modeli kullanılmıştır. Tarama modelleri, geçmişte ya da hâlen var olan bir durumu var olduğu şekliyle ve içinde bulunduğu koşullarda betimlemeyi amaçlayan yaklaşımlardır. Bu modelde araştırmaya konu olan olay, birey ya da nesne, kendi koşulları içinde ve olduğu gibi tanımlanmaya çalışılır (Karasar, 2003). Araştırma sürecinde akademik etik ilke ve sorumluluklara özen gösterilmiştir.

\section{Örneklem}

Çalışmada amaçlı örnekleme yöntemi kullanılmıştır. Bu araştırmanın örneklemini Millî Eğitim Bakanlığı tarafından mahallî olarak düzenlenen zekâ oyunları 1 ve 2 kursuna katılan öğretmenler ve idareciler; ortaokullarda seçmeli zekâ oyunları dersine giren öğretmenler; okul öncesi, ilkokul, ortaokul ve lise kademelerinde görev yapan ve halk eğitim merkezleri aracıllğı zekâ oyunlarıyla ilgili kurs açan öğretmenler oluşturmaktadır. Katılımcıların demografik özellikleri Tablo 1' de verilmiştir.

Tablo 1. Katılımcıların Demografik Özellikleri

\begin{tabular}{llll}
\hline \multirow{3}{*}{ Cinsiyet } & & $\mathrm{f}$ & $\%$ \\
& Erkek & 145 & 45,3 \\
Yaş & Kadın & 172 & 53,8 \\
& $25-30$ & 51 & 15,9 \\
& $31-35$ & 63 & 19,7 \\
& $36-40$ & 67 & 20,9 \\
& $41-45$ & 52 & 16,3 \\
\hline
\end{tabular}




\begin{tabular}{llll}
\hline \multirow{4}{*}{ Görev } & $46+$ & 84 & 26,3 \\
& Öğretmen & 287 & 89,7 \\
Kıdem & Okul Yöneticisi & 30 & 9,4 \\
& $0-5$ & 37 & 11,6 \\
& $6-10$ & 47 & 14,7 \\
& $11-15$ & 70 & 21,9 \\
Katılımcıların Görev & & 60 & 18,8 \\
Yaptıkları Okul & $16-20$ & 103 & 32,2 \\
& Anaokulu & 7 & 2,2 \\
& İlkokul & 173 & 54,1 \\
& Ortaokul & 107 & 33,4 \\
& Lise & 29 & 9,1 \\
\hline
\end{tabular}

\section{Veri Toplama Araçları}

Araştırmada kullanılan ölçme aracının geliştirilmesinde Ulusoy ve arkadaşlarının (2017) çalışmasından ve ilgili literatürden yararlanılmıştır. Veri toplama araçlarının geliştirilmesinde alan uzmanlarına ve ilgili konularda çalışan akademisyenlerle görüşmeler gerçekleştirilmiştir. Çalışmanın pilotlama aşaması Isparta ilinde resmi bir ilkokulda gerçekleştirilmiştir. Çalışmada kullanılan anket Likert tipinde ve 5 seçeneklidir. Ölçekteki her bir madde "tamamen katıliyorum (5)", "çoğunlukla katılıyorum (4)", "kısmen katılıyorum(3)", "katılmıyorum (2)" ve "hiç katılmıyorum (1)" biçiminde derecelendirilmiştir.

\section{Uygulama}

Literatür tarama ve anket geliştirme sürecinden sonra öncelikle akıl ve zekâ oyunları il koordinatörlerine ulaşılmıştır. İnternet ortamına taşınan anket il koordinatörleri aracılı̆̆ı ile zekâ oyunları eğitmenlerine ulaştırılmıştır. Anket formu 317 zekâ oyunları eğitmeni tarafından doldurulmuştur.

\section{Verilerin Analizi}

Araştırmada anket yoluyla toplanan verilerin analizinde istatistik programlarından yararlanılmıştır. Anketlerin analizinde her madde için 1-5 arası puanlar verilerek ölçme aracından toplanan veriler puanlandırılmıştır. 317 katılımcıdan gelen cevaplar ilişkin frekans ve yüzde, değerleri hesaplanmıştır. Ayrıca 317 ölçek ile faktör analizi ile güvenirlik analizleri yapılmıştır.

\section{Bulgular}

Analizlerde ölçeğin güvenirliğinin belirlenmesinde Cronbach Alpha güvenirlik katsayısı incelenmiştir ( $\alpha$ : 991). Yapı Geçerliliği için faktör analizi yapılmıştır. Faktör analizi sonuçları ve maddelere katılım düzeylerinin ortalama ve standart sapma değerleri Tablo 2’ de gösterilmiştir: 
Tablo 2. Faktör Analizi Sonuçları ve maddelere katılım düzeylerinin ortalama ve standart sapma değerleri

\section{Değişkenler}

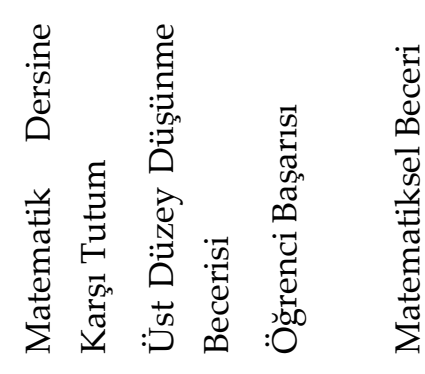

S22.Matematik kaygısını, korkusunu azaltır. .762

$4.40 \quad .683$

S15.Matematiksel kavramlara daha kolay .760

$4.41 \quad .664$

ulaşmayı sağlar.

S25.Matematikle ilgili ön yargıları giderir. $\quad 719$

matematiği de sevmelerini sağlar.

S13.Matematiğe karşı olumlu tutum geliştirmeyi $\quad .709$

sağlar.

S14.Matematiğin eğlenceli yönünü keşfetmeyi .674 sağlar.

S12.Matematikte dersinde başarıda artış sağlar. $\quad$.668

S11.Matematik-günlük hayat ilişkisi ile ilgili .638

farkındalık kazandırır.

S20.Matematiksel iletişimi geliştirir.

.626

S27.Sabırlı olmayı sağlar.

S28.Başarma hissini tatmayı sağlar.

S30.Bilgisayar oyunları, internet. cep telefonu.

tablet gibi teknolojik araçlara bağımlılı̆̆

azaltmada etkili bir yöntemdir.

S26.Öğretmenle iletişimi kolaylaştırır.

S24.Derse katılma isteğini arttırır.

S29.Öğrencilere sempatik geldiğinden olumlu

tutum geliştirmeye katkı sağlar. 
S17.Problem çözmeye katkı sağlar (İşlem yolları geliştirme gibi).

S8.Zekâyı verimli kullanabilmeyi sağlar, çoklu

türünü geliştirir.

S18.Akıl yürütmeye katkı sağlar (Rakibin bir

bakma; sebep-sonuç ilişkisi kurma gibi).

S7.Çok yönlü düşünmeye, farklı açılardan

S21.Dersi zevkli hale getirir.

S10.İşlem kabiliyetini geliştirir, sayılar arasındaki

ilişkileri fark etmeyi sağlar.

S9.Hazırbulunuşluk düzeyini arttırır.

S2.Akıl-zekâ oyunlarının matematik eğitimine .773

S3.Akıl-zekâ oyunlarının temel matematiksel becerilere (problem çözme, akıl yürütme. matematiksel iletişim, ilişkilendirme) katkısı olmaktadır.

S4.Akıl-Zekâ oyunlarının öğrencilerin matematikle ilgili özelliklerine (matematik kaygısı, matematiğe yönelik tutum, matematiğe karşı özyeterlik) olumlu katkıları olmaktadır.

S5.Problem çözme, akıl yürütme, sebep-sonuç $\begin{array}{lll}.627 & 4.69 \quad .487\end{array}$ ilişkisi kurma, analiz etme, analitik düşünme, hızlı ve pratik düşünme, çok boyutlu ve soyut düşünme, strateji geliştirme becerilerini geliştirir. 
Faktör analizi sonucunda matematik dersine karşı tutum, üst düzey düşünme becerisi, öğrenci başarısı ve matematiksel beceri olmak üzere 4 boyuta ulaşılmıştır.

\section{Korelasyon Analizi}

Çalışmanın bu bölümünde matematik dersine karşı tutum, üst düzey düşünme becerileri, öğrenci başarısı ile matematiksel beceri değişkenleri arasındaki ilişki korelasyon analiz yapılarak test edilmiştir. Tablo (3)'de korelasyon analizi sonuçları yer almaktadır.

Tablo 3. Korelasyon Analizi

\begin{tabular}{lllll}
\hline & 1 & 2 & 3 & 4 \\
Matematik Dersine Karşı Tutum & 1 & & & \\
Üst Düzey Düşünme Becerileri & $.892^{* *}$ & 1 & & \\
Öğrenci Başarısı & $.897^{* *}$ & $.951^{* *}$ & 1 & 1 \\
Matematiksel Beceri & $.884^{* *}$ & $.873^{* *}$ & $.910^{* *}$ & \\
\hline$* * 00.01$ & & & & \\
\hline
\end{tabular}

Pearson Korelasyon analizine göre Matematik Dersine Karşı Tutum, Üst Düzey Düşünme Becerileri, Öğrenci Başarısı ile Matematiksel Beceri değişkenleri arasındaki pozitif yönde ilişki söz konusudur. Buna göre; Matematik Dersine Karşı Tutum ile Üst düzey düşünme becerileri arasında pozitif yönde güçlü bir ilişki (.892); Öğrenci Başarısı arasında pozitif yönde güçlü bir ilişki (.897) matematiksel beceri arasında pozitif yönde güçlü bir ilişki (.884) vardır. Üst Düzey Düşünme Becerisi ile Öğrenci Başarısı arasında pozitif yönde güçlü bir ilişki (.951). Matematiksel Beceri arasında pozitif yönde güçlü bir ilişki (.873) vardır. Öğrenci Başarısı ile Matematiksel Beceri arasında pozitif yönde güçlü bir ilişki (.910) vardır.

Katılımcıların demografik özelliklerine göre değişkenler arasında farklılıkların olup olmadığını belirlemek amacıyla T Testi ve Varyans analizleri yapılmıştır. Katılımcıların cinsiyetlerine göre değişkenler arası bir farkın olup olmadığı $\mathrm{T}$ testi ile sınanmıştır. Analizler sonucunda cinsiyete göre değişkenler arasında anlamlı bir fark bulunamamıştır. Katılımcıların görevlerine (öğretmen veya yönetici) göre değişkenler arası bir farkın olup olmadığı $\mathrm{T}$ testi ile sınanmıştır. Analizler sonucunda görev türüne göre değişkenler arasında anlamlı bir fark bulunamamıştır. Katılımcıların yaş gruplarına göre değişkenler arasında anlamlı bir farkın olup olmadığını belirlemek amacıyla varyans analizi yapılmıştır. Analiz sonucunda katılımcıların yaşlarına göre sadece "'matematiksel beceri" değişkeninde anlamlı bir farklılık olduğu gözlemlenmiştir. Katılımcıların Yaşlarına Göre "Matematiksel Beceri" Değişkeninde Anlamlı Bir Farkın Olup Olmadığını Belirlemek Amacıyla Yapılan Tek Yönlü Varyans Analizi Sonuçları Tablo 4'te gösterilmiştir.

Tablo 4. Katılımcıların Yaşlarına Göre “Matematiksel Beceri” Değişkeninde Anlamlı Bir Farkın Olup Olmadığını Belirlemek Amacıyla Yapılan Tek Yönlü Varyans Analizi Sonuçları

\begin{tabular}{llllllll}
\hline Değişken & $\begin{array}{l}\text { Kıdem } \\
\text { Grubu }\end{array}$ & $\mathrm{N}$ & $\mathrm{X}$ & $\mathrm{SS}$ & $\mathrm{F}$ & $\mathrm{P}$ & Anlamlı Fark \\
Matematik Beceri & $25-30$ & 48 & 4.53 & .44 & 3.31 & 0.011 & $41-45$ yaş ile $46+$ \\
\hline
\end{tabular}




\begin{tabular}{lllll}
\hline $31-35$ & 57 & 4.64 & .41 & yaş arasında \\
$36-40$ & 54 & 4.61 & .50 \\
$41-45$ & 45 & 4.38 & .59 \\
$46+$ & 72 & 4.69 & .43 \\
\hline
\end{tabular}

Analiz sonucunda katılımcıların yaşlarına göre sadece "Matematiksel Beceri" değişkeninde anlamlı bir farklılık olduğu gözlemlenmiştir. 41-45 ile 46+ yaş grupları arasında anlamlı farklılık belirlenmiştir. 41-45 yaş grubunda madde ortalamalarını değeri en düşük değer olan $4.3833^{\prime}$ tür. Bu durum 41-45 yaş aralığındaki eğitmenler diğer yaş gruplarına göre; akıl ve zekâ oyunlarının öğrencilerin matematiksel becerileri üzerindeki pozitif etkisinin daha az olduğunu belirtmişlerdir. Matematiksel beceri değişkeni değerlerinde dikkat çekici diğer bir nokta da 25-30 yaş aralığındaki eğitmenlerin verdikleri cevapların ortalama değerinin ikinci en düşük oran olmasıdır (4.5313). Bu değerlere bakarak mesleğe yeni başlayan eğitmenlerin diğer yaş gruplarına göre, akıl ve zekâ oyunlarının öğrencilerin matematiksel becerileri üzerinde etkisinin daha az olduğunu düşündükleri söylenebilir. Katılımcıların kıdemlerine göre değişkenler arasında anlamlı bir farkın olup olmadığını belirlemek amacıyla yapılan tek yönlü varyans analizi yapılmıştır. Analiz sonucunda matematik dersine karşı tutum, üst düzey düşünme becerileri, öğrenci başarısı ve matematiksel beceri değişkenlerinde gruplar arası anlamlı farklılıklar olduğu görülmüştür. Katılımcıların Kıdemlerine Göre "Matematik Dersine Karşı Tutum" Değişkeninde Anlamlı Bir Farkın Olup Olmadığını Belirlemek Amacıyla Yapılan Tek Yönlü Varyans Analizi Sonuçları Tablo 5’te verilmiştir.

Tablo 5. Katılımcıların Kıdemlerine Göre “Matematik Dersine Karşı Tutum” Değişkeninde Anlamlı Bir Farkın Olup Olmadığını Belirlemek Amacıyla Yapılan Tek Yönlü Varyans Analizi Sonuçları

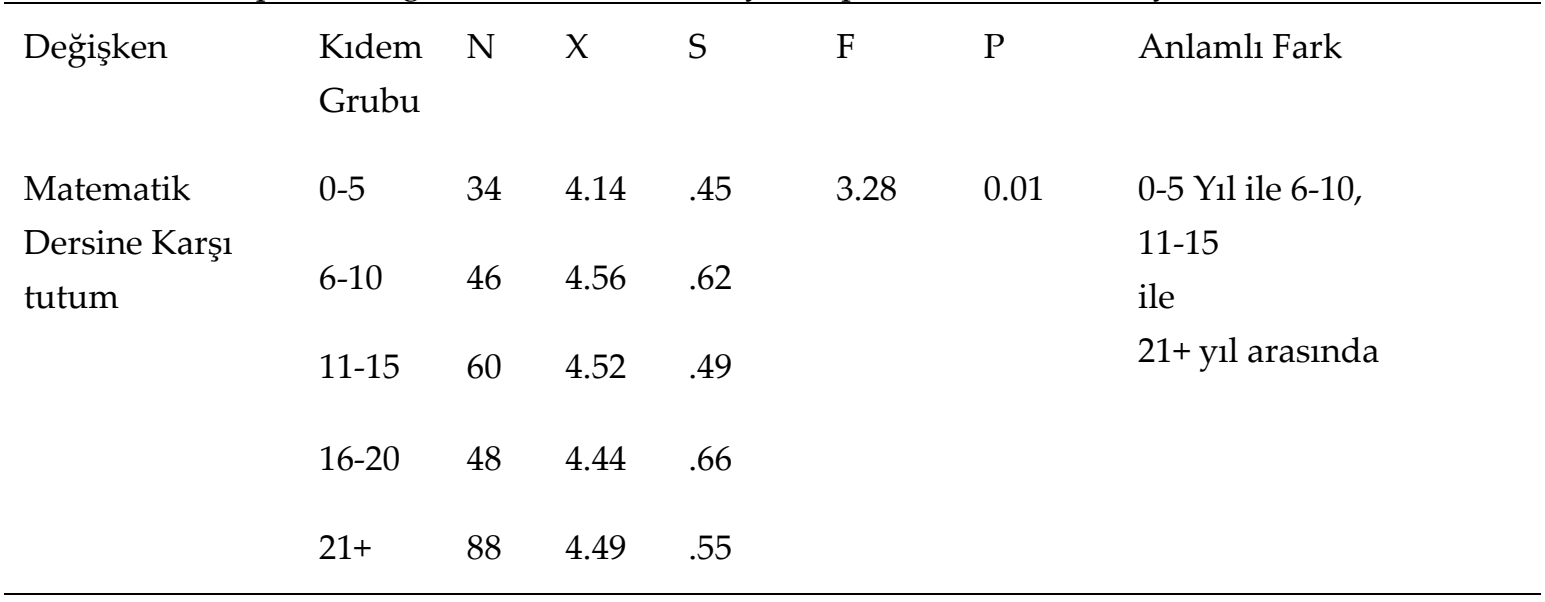

Katılımcıların kıdemlerine göre "Matematik Dersine Karşı Tutum" değişkeninde anlamlı bir farkın olup olmadığını belirlemek amacıyla yapılan tek yönlü varyans analizine göre; 0-5 Yıl ile 6-10. 11-15 ve 21+ yıl grupları arasında anlamlı farklılıklar bulunmaktadır. Buna göre mesleğe yeni başlayan eğitmenlerin diğer yaş gruplarına göre, akıl ve zekâ oyunlarının öğrencilerin matematik dersine karşı tutumları üzerindeki pozitif etkisinin daha az olduğunu düşündükleri söylenebilir.

Katılımcıların Kıdemlerine Göre “Üst Düzey Düşünme Becerileri” Değişkeninde Anlamlı Bir Farkın Olup Olmadığını Belirlemek Amacıyla Yapılan Tek Yönlü Varyans Analizi Sonuçları Tablo $6^{\prime}$ da verilmiştir. 
Tablo 6. Katılımcların Kıdemlerine Göre "Üst düzey düşünme becerileri” Değişkeninde Anlamlı Bir Farkın Olup Olmadığını Belirlemek Amacıyla Yapılan Tek Yönlü Varyans Analizi Sonuçları

\begin{tabular}{llllllll}
\hline Değişken & $\begin{array}{l}\text { Kidem } \\
\text { Grubu }\end{array}$ & $\mathrm{N}$ & $\mathrm{X}$ & $\mathrm{SS}$ & $\mathrm{F}$ & $\mathrm{P}$ & $\begin{array}{l}\text { Anlaml } \\
\text { Fark }\end{array}$ \\
$\begin{array}{l}\text { Üst Düzey } \\
\begin{array}{l}\text { Düşünme } \\
\text { Becerileri }\end{array}\end{array}$ & $0-5$ & 34 & 4.33 & .45 & 3.52 & 0.00 & $\begin{array}{l}0-5 \text { Yil ile } \\
\end{array}$ \\
& $6-10$ & 46 & 4.67 & .44 & & & $6-10$, \\
& $11-15$ & 60 & 4.68 & .43 & & $\begin{array}{l}11-15 \text { ile } \\
\text { arasinda }\end{array}$ \\
& $16-20$ & 48 & 4.58 & .54 & & \\
& $21+$ & 88 & 4.61 & .47 & & & \\
\hline
\end{tabular}

Katılımcıların kıdemlerine göre "Üst düzey düşünme becerileri" değişkeninde anlamlı bir farkın olup olmadığını belirlemek amacıyla yapılan tek yönlü varyans analizine göre; 0-5 Yıl ile 6-10. 11-15 ve 21+ yıl arasında anlamlı farklılıklar bulunmaktadır. Buna göre mesleğe yeni başlayan eğitmenlerin diğer yaş gruplarına göre akıl ve zekâ oyunlarının öğrencilerin üst düzey düşünme becerileri üzerindeki pozitif etkisinin daha az olduğunu düşündükleri söylenebilir.

Katılımcıların Kıdemlerine Göre "Öğrenci Başarısı" Değişkeninde Anlamlı Bir Farkın Olup Olmadığını Belirlemek Amacıyla Yapılan Tek Yönlü Varyans Analizi Sonuçları Tablo 7'de verilmiştir.

Tablo 7. Katılımcıların Kıdemlerine Göre "Öğrenci Başarısı” Değişkeninde Anlamlı Bir Farkın Olup Olmadığını Belirlemek Amacıyla Yapılan Tek Yönlü Varyans Analizi Sonuçları

\begin{tabular}{llllllll}
\hline Değişken & $\begin{array}{l}\text { Kıdem } \\
\text { Grubu }\end{array}$ & $\mathrm{N}$ & $\mathrm{X}$ & $\mathrm{SS}$ & $\mathrm{F}$ & $\mathrm{P}$ & Anlamlı Fark \\
Öğrenci Başarısı & $0-5$ & 34 & 4.43 & .41 & 2.76 & 0.02 & $\begin{array}{l}0-5 \text { Y1l ile 6-10 } \\
\text { ve 11-15 yıl } \\
\text { arasında }\end{array}$ \\
& $6-10$ & 46 & 4.72 & .40 & & & \\
$11-15$ & 60 & 4.70 & .39 & & \\
$16-20$ & 48 & 4.66 & .45 & \\
& $21+$ & 88 & 4.63 & .46 & & \\
\hline
\end{tabular}

Katılımcıların kıdemlerine göre "Öğrenci Başarısı" değişkeninde anlamlı bir farkın olup olmadığını belirlemek amacıyla yapılan tek yönlü varyans analizine göre; 0-5 Yıl ile 6-10 ve 11-15 yıl arasında anlamlı farklılıklar bulunmaktadır. Buna göre mesleğe yeni başlayan eğitmenlerin diğer yaş gruplarına göre akıl ve zekâ oyunlarının öğrencilerin başarısı üzerindeki pozitif etkisinin daha az olduğunu düşündükleri söylenebilir.

Katılımcıların Kıdemlerine Göre "Matematiksel Beceri" Değişkeninde Anlamlı Bir Farkın Olup Olmadığını Belirlemek Amacıyla Yapılan Tek Yönlü Varyans Analizi Sonuçları Tablo 8'de verilmiştir. 
Tablo 8. Katılımcıların Kıdemlerine Göre “Matematiksel Beceri” Değişkeninde Anlamlı Bir Farkın Olup Olmadığını Belirlemek Amacıyla Yapılan Tek Yönlü Varyans Analizi Sonuçları

\begin{tabular}{|c|c|c|c|c|c|c|c|}
\hline Değişken & $\begin{array}{l}\text { Kidem } \\
\text { Grubu }\end{array}$ & $\mathrm{N}$ & $X$ & SS & $\mathrm{F}$ & $\mathrm{P}$ & $\begin{array}{l}\text { Anlamlı } \\
\text { Fark }\end{array}$ \\
\hline \multirow{5}{*}{$\begin{array}{l}\text { Matematiksel } \\
\text { Beceri }\end{array}$} & $0-5$ & 34 & 4.37 & .44 & \multirow[t]{5}{*}{2.968} & \multirow[t]{5}{*}{0.020} & \multirow{5}{*}{$\begin{array}{ll}0-5 \quad \text { Yil ile } \\
11-15 \quad \text { yil } \\
\text { arasında }\end{array}$} \\
\hline & $6-10$ & 46 & 4.66 & .42 & & & \\
\hline & $11-15$ & 60 & 4.67 & .43 & & & \\
\hline & $16-20$ & 48 & 4.50 & .59 & & & \\
\hline & $21+$ & 88 & 4.61 & .47 & & & \\
\hline
\end{tabular}

Katılımcıların kıdemlerine göre "Matematiksel Beceri" değişkeninde anlamlı bir farkın olup olmadığını belirlemek amacıyla yapılan tek yönlü varyans analizine göre; 0-5 Yıl ile 11-15 yıl arasında anlamlı farklılıklar bulunmaktadır. Buna göre mesleğe yeni başlayan eğitmenlerin diğer yaş gruplarına göre akıl ve zekâ oyunlarının öğrencilerin matematiksel becerileri üzerindeki pozitif etkisinin daha az olduğunu düşündükleri söylenebilir.

\section{Tartışma, Sonuç ve Öneriler}

Bu çalışmada resmî eğitim kurumlarında görev yapan akıl ve zekâ oyunları eğitmenlerinin akıl ve zekâ oyunlarının öğrencilere katkıları hakkındaki görüşlerinin belirlenmesi amaçlanmıştır. Katılımcıların yaptıkları değerlendirmelere göre; akıl ve zekâ oyunları matematik dersine karşı tutum, üst düzey düşünme becerileri, öğrenci başarısı ile matematiksel beceriler üzerinde pozitif yönde etkilidir. Özellikle üst yaş grubunda yer alan ve daha fazla kıdeme sahip eğitmenlerin akıl ve zekâ oyunlarının öğrencilere katkılarının daha fazla olduğunu düşündükleri görülmektedir. Bunun yanında farklı seviye eğitim kurumlarında yöneticilik ve öğretmenlik yapan akıl ve zekâ oyunları eğitmenlerinin genel olarak akıl ve zekâ oyunlarının öğrencilere pozitif yönde katkılarının olduğunu düşündükleri ancak bu katkının hangi alanlarda olduğu konusunda belirsizlik yaşadıkları gözlemlenmektedir. Araştırma sonuçları konuyla ilgili gerçekleştirilen çalışmaların sonuçlarıyla örtüşmektedir.

Güneş ve Yünkül'ün (2021) gerçekleştirdiği çalışmanın bulgularına göre öğretmenler akıl ve zekâ oyunlarını genellikle serbest etkinlikler ve oyun ve fiziki etkinlikler derslerinde oynattıklarını belirtmişlerdir. Öğretmenler akıl ve zekâ oyunlarını en çok matematik derslerinde kullandıklarını ve matematik dersinde de akıl ve zekâ oyunlarından çoğunlukla geometrik cisimler konusunda yararlandıklarını ifade etmişlerdir. Baş, Kuzu ve Gök (2020) yaptıkları ve bu araştırma ile aynı hedef grubunu kapsayan çalışmada ilkokul çağında üstün zekalı olarak tanımlanan öğrencilerin oynadıkları çeşitli akıl oyunlarının onların analitik düşünme, eleştirel düşünme ve karar verme becerilerine etkisini ortaya koymak amaçlanmıştır. Araştırma sonuçları, üstün yetenekli öğrencilerin oynadıkları çeşitli akıl oyunları sonucunda analitik düşünme, eleştirel düşünme ve karar verme becerilerinin geliştiğini göstermiş bu çalışmanın sonuçlarıyla örtüşmüştür. Diğer taraftan analiz ve sentez yeteneği gerektiren yazma becerisinin incelendiği bir araştırmanın sonuçları bu araştırma sonuçlarıyla benzerlik göstermektedir. Kuzu ve Durna'nın (2020) gerçekleştirdikleri ve Türkçe Dersi Öğretim Programının içerik ve kazanımlarına uygun olarak seçilen Zekâ ve Akıl Oyunlarının yazma sürecine etkisinin incelendiği araştırmada Zekâ ve Akıl Oyunları özellikle yazmaya hazırlık aşamasında etkili olduğu ve Zihin Oyunları ile derslerin işlendiği gruptaki öğrencilerin klasik dersin işlendiği gruptaki öğrencilere göre yazma konusunda daha başarılı oldukları tespit edilmiştir. Deney grubundaki öğrencilerin de ilgi ve dikkatlerinin arttığı gözlemlenmiştir. Bu araştırmada katılımcların akıl ve zekâ 
oyunlarıyla genel olarak olumlu bir algıya sahip oldukları belirlenmiştir. Araştırma sonuçları Sargın ve Taşdemir (2020) tarafından öğretmenlerle yürütülen çalışmada elde edilen bulgularla örtüşmektedir. Sargın ve Taşdemir katılımcıların zekâ oyunları dersi öğretimi programı hakkında okul öncesi eğitime ve ilkokul programına zekâ oyunları dersi ve programının eklenmesi gerektiğini düşündüklerini belirlemiştir. Demirel ve Yılmaz (2016) tarafından gerçekleştirilen bir çalışmada; akıl oyunlarının Matematik ve Türkçe derslerinde kullanılması: geliştirme süreci ve öğretmen-öğrenci görüşleri incelenmiştir. Çalışmada birçok akıl oyunu Türkçe ve Matematik dersi kazanımlarını sağlayacak ya da destek olacak şekilde uyarlanmıştır. Araştırma sonucunda öğretmen ve öğrencilerin görüşlerinin genel olarak olumlu olduğu görülmüştür. Öğretmenlere göre akıl oyunları uygulamaları öğrencilerinin düşünme becerilerini geliştirmekte, akademik başarılarına olumlu etkisi olmakta ve derse aktif katılımı sağlamakta olduğu tespitlerine varmışlardır.

Araştırma sonuçlarından elde edilen bulgulara bakarak mesleğe yeni başlayan ve meslekî kıdemleri 0-5 yıl arasında olan eğitmenlerinin diğer kıdem gruplarına göre; akıl ve zekâ oyunlarının öğrencilerin matematik dersine karşı tutumları, matematiksel becerileri, üst düzey düşünme becerileri ve genel olarak öğrenci başarısı üzerindeki pozitif etkisinin daha az olduğunu düşündükleri belirlenmiştir. $\mathrm{Bu}$ gruptaki eğitmen görüşlerinin görece kıdemli eğitmen görüşlerinden farklılaşmasının; öğrencileri gözlemleme, izleme ve değerlendirme tecrübe ve yaşantılarının daha az olmasından kaynaklandığı düşünülmektedir. Sonuç olarak eğitim kurumlarında akıl ve zekâ oyunlarıyla ilgili olarak yürütülen çalışmalara ve uygulamalara yönelik aşağıdaki öneriler siralanabilir:

- Eğitmenlerin akıl ve zekâ oyunlarının hangi alanlarda öğrencilere katkı sağladığı konusunda daha net bir anlayış edinmelerine yardımcı olmak amacıyla doğrudan uygulamaya yönelik çalışmalar yapılmalıdır.

- Akıl ve zekâ oyunlarının öğrencilere katkısı konusunda uygulamalı araştırmaların sayısı artırılmalıdır. Bu çalışmalarda farklı okul türleri, kademeleri ve öğrenci grupları örneklem olarak seçilmelidir.

- Öncelikle akıl ve zekâ oyunlarının öğrencilere olan katkıları hakkında okul yöneticileri, aileler ve öğretmenlere yönelik farkındalık ve bilinçlendirilme çalışmaları gerçekleştirilmelidir. Bu çalışmalarda akıl ve zekâ oyunlarının öğrencilerin gelişimlerine ve akademik başarılarına olan katkısı özellikle vurgulanmalıdır.

- Eğitim programları hazırlanırken; akıl ve zekâ oyunlarının öğrencilerin matematiksel becerilerine, matematik dersine, üst düzey düşünme becerilerine ve genel olarak akademik başarılarına olan katkıları göz önünde bulundurulmalı, bu konuda sistemli bir yaklaşım ortaya konulmalıdır.

- Akıl ve zekâ oyunları eğitiminin öğretmenlik mesleğinin başlangıcından itibaren etkin ve verimli olarak uygulanabilmesi için öncelikle eğitim fakültelerinde zorunlu ya da seçmeli ders olarak okutulmalıdır.

\section{Araştırma ve Yayın Etiği Beyanı}

Araştırma sürecinde akademik etik ilke ve sorumluluklara özen gösterilmiştir. Makalenin tüm süreçlerinde UBED 'in araştırma ve yayın etiği ilkelerine uygun olarak hareket edilmiştir "Akıl ve Zekâ Oyunlarının Öğrencilere Katkıları: Eğitmenlerin Görüşleri" makalesi özgün bir araştırma makalesidir. Başka yerde yayımlanmamış ya da yayımlanmak üzere gönderilmemiştir. Makalede yararlanılan kaynaklara etik ilkeler doğrultusunda doğru biçimde atıf yapılmıştır.

Yazarların Makaleye Katkı Oranları

Yazarlar çalışmaya eşit oranda katkı sağlamıştır.

\section{Çıkar Beyanı}


Bu çalışmada yazarlar arasında çıkar çatışması bulunmamaktadır.

\section{Kaynakça}

Bas, O. , Kuzu, O. and Gök, B. (2020). The Effects of Mind Games on Higher Level Thinking Skills in Gifted Students . Journal of Education and Future , (17) , 1-13 . DOI: 10.30786/jef.506669

Bottino, R. M., Ott, M. \& Tavella, M. (2013). Investigating the Relationship Between School Performance and the Abilities to Play Mind Games. In European Conference on Games Based Learning, 62. Academic Conferences International Limited. p. 62-71.

Demirel, T. ve Karakuş Yılmaz, T. (2016). Akıl Oyunlarının Matematik ve Türkçe Derslerinde Kullanılması: Geliştirme Süreci ve Öğretmen-Öğrenci Görüşleri, XVIII. Akademik Bilişim Konferansı, Aydın, Türkiye.

Devecioğlu. Y. ve Karadağ. Z. (2014). Amaç. Beklenti ve Öneriler Bağlamında Zekâ Oyunları Dersinin Değerlendirilmesi. Bayburt Üniversitesi Ĕ̆itim Fakültesi Dergisi. 9 (1). s.41-61.

Ellis. H. C.. Hunt. R. R. (1993). Fundementals of cognitive psychology. Mc Graw Hill.

Garris. R.. Ahlers. R.. \& Driskell. J. (2002). Games, motivation and learning: A research and practice model, 33(4). 441-467.

Gündüz, M., Aktepe, V., Uzunoğlu, H. ve Gündüz, D. D. (2017). Okul Öncesi Dönemdeki Çocuklara Eğitsel Oyunlar Yoluyla Kazandırılan Değerler. Muğla Sıtkı Koçman Üniversitesi Eğitim Fakültesi Dergisi, 4(1), 62-70., doi: 10.21666/Muefd.303856

Güneş. H. ve Demirtaş. H. (2002). Üçüncü Bin Yılda Üniversiteler ve Toplumsal Kalkınma. Eğitim Araştırmaları Dergisi. Sayı: 7 (0), 33-44.

Güneş, D. ve Yünkül, E. (2021). Sınıf Öğretmenlerinin Akıl ve Zekâ Oyunlarının İlkokulda Kullanımına Yönelik Değerlendirmeleri. Uluslararası Sosyal Bilimler Akademi Dergisi , (5) , 784-803 Yayınları.

Karasar, N. (2003). Bilimsel Araştırma Yöntemi. (Scientific Research Methods ). Ankara: Nobel

Kula, S. S. (2020). Zekâ Oyunlarının İlkokul 2. Sınıf Öğrencilerine Yansımaları: Bir Eylem Araştırması . Milli Ĕ̆itim Dergisi, 49 (225) , 253-282 .

Kuzu, T. S. and Durna, C. (2020). The Effect of Intelligence and Mind Games on Secondary School Students' Writing Success, Turkish Online Journal of Educational Technology - TOJET, v19 n3 p7079 Jul 2020

Lester. F. K. (1994). Musing about mathematical problem solving researchs: 1970-1994. Journal for Research in Mathematics Education. Say1: 25(6), 660-675.

Lou. Y.. Abrami. P.. \& D'Apollonia. S. (2001). Small group and individual learning with technology: a meta-analysis. Review of Educational Research. 71(3). 449-521.

Mackey. A. P..Hill. S. S.. Stone. S. I.. \& Bunge. S. A. (2011). Differential effects of reasoning and speed training in children. Developmental Science. 14(3). 582-590. 
Milli Eğitim Bakanlığı. (2013). Ortaokul ve imam hatip ortaokulu zekâ oyunları dersi (5, 6, 7, 8. sinıflar) öğretim programı. Ankara: Devlet Kitapları Müdürlüğü Basım Evi.

Muller. A. A.. \& Pearlmutter. M. (1985). Preschool children's problem-solving interactions at computers and jigsaw puzzles. Journal of Applied Developmental Psychology. 6(2). 173-186.

Ott. M.. \& Pozzi. F. (2012). Digital games as creativity enablers for children. Behaviour \& Information Technology. 31(10). 1011-1019.

Rosas. R.. Nussbaum. M.. Cumsille. P.. Marianov. V.. Correa. M.. Flores. P.. \& Salinas. M. (2003). Beyond Nintendo: design and assessment of educational video games for first and second grade students. Computer \& Education. 40(1). 71-94.

Sargın, M. ve Taşdemir, M. (2020). Seçmeli Zekâ Oyunları Dersi Öğretim Programının Öğretmenler Tarafından Değerlendirilmesi (Bir Durum Çalışması) . Elektronik Sosyal Bilimler Dergisi , 19 (75) , 1444-1460 . DOI: 10.17755/esosder.653817

Ulusoy. Ç. A.. Saygı. E.. ve Umay. A. (2017). İlköğretim Matematik Öğretmenlerinin Zekâ Oyunları Dersi ile İlgili Görüşleri Views of Elementary Mathematics Teachers about Mental Games Course. Hacettepe Üniversitesi Ĕ̆itim Fakültesi Dergisi. 32(2). 280-294.

Verschaffel. L.. De Corte. E.. Lasure. S.. Van Vaerenbergh. G.. Boagerts. H.. \& Ratincky. E. (1999). Learning to solve mathematical application problems: A design experiment with fifth graders. Mathematical Thinking \& Learning. 1(3). 195-229. doi: 10.1207/s15327833mt10103_2

\section{EXTENDED SUMMARY}

In the 21st century, there is a greater need for qualified human resources with innovative and productive features, who train leaders who compete with the world, adapt to the changing world, transform what they have learned into practice, analyze, synthesize and evaluate. Among individuals with these characteristics; creativity and innovation, leadership and responsibility, communication and cooperation, productivity and accountability, knowledge, media and technology skills, critical, analytical, thinking and problem solving skills come forward. Mind and intelligence games are an important teaching technique in terms of making the teaching process more efficient for both students and teachers and reaching the targeted gains. If evaluated from the point of view of the learner, intelligence games save the lesson from monotony, increase the attention, concentration and motivation level of the student, directly address all development areas, contribute to permanent learning as well as providing the student with the opportunity to learn by doing and experiencing, offering important opportunities such as learning while having fun and having fun while learning. Thus, it is an important teaching technique that increases the course processing time. If evaluated in terms of the teacher, intelligence games offer important opportunities such as easily addressing different intelligence areas of students with different game types, evaluating individual differences, actively involving the student in the lesson, and teaching by having fun with the students in the teaching process. Intelligence games can be defined as activities offered so that individuals can realize their own potential, make quick and correct decisions, produce unique solutions to problems, and most importantly, constantly renew themselves.

\section{Method}

Survey model was used in this study. Survey models are approaches that aim to describe a past or present situation as it exists and in its current conditions. In this model, the event, individual 
or object that is the subject of the research is tried to be defined in its own conditions and as it is. Purposive sampling method was used in the study. The sample of this research is teachers and administrators who participated in intelligence games 1 and 2 courses organized locally by the Ministry of National Education. It consists of teachers who work at pre-school, primary, secondary and high school levels and open courses on intelligence games through public education centers. The study of Ulusoy et al. (2017) and the relevant literature were used in the development of the measurement tool used in the research. In the development of data collection tools, interviews were held with field experts and academicians working on related subjects. The piloting phase of the study was carried out in an official primary school in the province of Isparta. The questionnaire used in the study is Likert type and has 5 options. Each item in the scale was graded as "strongly agree (5)", "mostly agree (4)", "partially agree (3)", "disagree (2)" and "strongly disagree (1)". After the literature review and questionnaire development process, first of all, the provincial coordinators of mind and intelligence games were reached. The questionnaire, which was transferred to the internet environment, was delivered to the mind games trainers through the provincial coordinators. The questionnaire was filled by 317 intelligence games trainers.

\section{Findings and Discussion}

As a result of factor analysis, 4 dimensions were reached: attitude towards mathematics lesson, high-level thinking skills, student achievement and mathematical skills. According to Pearson Correlation analysis, there is a positive relationship between attitudes towards mathematics, highlevel thinking skills, student achievement and mathematical skill variables. According to this; A strong positive correlation between Attitudes Towards Mathematics Lesson and Higher Level Thinking Skills (.892); There is a strong positive relationship between Student Achievement (.897) and a strong positive relationship (.884) between mathematical skills. A strong positive correlation between High Level Thinking Skill and Student Achievement (.951). There is a strong positive correlation (.873) between Mathematical Skills. There is a strong positive correlation (.910) between Student Success and Mathematical Skills. In order to determine whether there are differences between the variables according to the demographic characteristics of the participants, T-Test and Variance analyzes were performed. As a result of the analysis, no significant difference was found between the groups according to gender and task type. In addition, it was observed that there was a significant difference only in the "mathematical skill" variable according to the age of the participants. Trainers between the ages of 41-45 compared to other age groups; stated that the positive effect of mind and intelligence games on students' mathematical skills is less.

Another remarkable point in the values of the mathematical skills variable is that the average value of the answers given by the instructors in the 25-30 age range is the second lowest rate (4.53). By looking at these values, it can be said that the educators who have just started their profession think that the effect of mind and intelligence games on the mathematical skills of the students is less compared to other age groups.

In addition, as a result of the analysis, it was seen that there were significant differences between the groups in the variables of attitude towards mathematics lesson, high-level thinking skills, student achievement and mathematical skills. According to the one-way analysis of variance conducted to determine whether there is a significant difference in the "Attitude Towards Mathematics Lesson" variable according to the seniority of the participants, it can be said that the instructors who have just started their profession think that the positive effect of mind and intelligence games on students' attitudes towards mathematics lesson is less than other age groups.

According to the one-way analysis of variance carried out to determine whether there is a significant difference in the "high-level thinking skills" variable according to the seniority of the 
participants, it can be said that the new instructors think that the positive effect of mind and intelligence games on the higher-order thinking skills of the students is less than the other age groups. Finally, according to the results of the research, it can be said that the new instructors think that the positive effect of mind and intelligence games on the success of the students is less than the other age groups. According to the evaluations of the participants; Mind and intelligence games have a positive effect on attitudes towards mathematics, high-level thinking skills, student success and mathematical skills. It is seen that especially the instructors who are in the upper age group and have more seniority think that mind and intelligence games contribute more to the students.

In addition, it is observed that mind and intelligence games trainers, who work as administrators and teachers at different educational institutions, generally think that mind and intelligence games have positive contributions to students, but they are uncertain about the areas in which this contribution is. The results of the research coincide with the results of the studies carried out on the subject. By looking at the findings obtained from the research results, compared to the other seniority groups of the trainers who are new to the profession and whose professional seniority is between 0-5 years; It was determined that they thought that mind and intelligence games had less positive effects on students' attitudes towards mathematics lesson, mathematical skills, higher-order thinking skills and overall student success. The fact that the views of the instructors in this group differ from those of the relatively senior instructors; It is thought that it is due to the fact that they have less experience and experience of observing, monitoring and evaluating students.

As a result, the following suggestions can be listed for the studies and practices carried out on mind and intelligence games in educational institutions:

- In order to help trainers gain a clearer understanding of the areas in which mind and intelligence games contribute to students, direct practice studies should be carried out.

- The number of applied studies on the contribution of mind games to students should be increased. In these studies, different school types, grades and student groups should be selected as samples.

- First of all, awareness-raising activities should be carried out for school administrators, families and teachers about the contribution of mind and intelligence games to students. In these studies, the contribution of mind games to the development and academic success of students should be especially emphasized. 